\title{
Adrenal Cancer pNX TNM Finding v7
}

National Cancer Institute

\section{Source}

National Cancer Institute. Adrenal Cancer pNX TNM Finding v7. NCI Thesaurus. Code C89406.

Adrenal cancer in which the regional lymph nodes cannot be assessed. (from AJCC 7th Ed.) 